\title{
The correlation between self-efficacy and peer interaction towards students' employability in vocational high school
}

\author{
Fatwa Tentama, Muhammad Zulfikar Nur
}

Faculty of Psychology, Universitas Ahmad Dahlan, Indonesia

\begin{tabular}{l} 
Article Info \\
\hline Article history: \\
Received Mar 8, 2020 \\
Revised Nov 17, 2020 \\
Accepted Jan 12, 2021 \\
\hline
\end{tabular}

\section{Keywords:}

Employability

Peer interaction

Self-efficacy

\begin{abstract}
Employability is an important factor that can determine the quality of prospective graduates, especially in vocational high schools. Therefore, vocational high schools, as one of the educational institutions that prepare workforce resources, need to pay attention to factors that can increase their students' employability. This study aims to empirically examine the role of self-efficacy and the peer interaction on student employability. The subjects of this study were 132 students at Vocational High School Muhammadiyah Prambanan. The data were collected through an employability scale, a selfefficacy scale, and a peer interaction scale. The data were then analyzed with multiple linear regression techniques. The results showed that: 1) Simultaneously, there was a very significant role that self-efficacy and peer interaction have on employability with $\mathrm{p}=0.000(\mathrm{p}<0.01)$; 2) Partially, there was also a very significant role that self-efficacy has on employability with $\mathrm{p}=0.000(\mathrm{p}<0.01) ; 3)$ Peer interaction also had a partially significant role on employability with $\mathrm{p}=0.001(\mathrm{p}<0.01)$. Both self-efficacy and peer interaction simultaneously contributed $40.8 \%$ to employability, but self-efficacy had a more dominant role $(26.7 \%)$ than peer interactions $(14.1 \%)$.
\end{abstract}

This is an open access article under the CC BY-SA license.

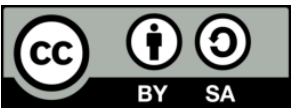

\section{Corresponding Author:}

Fatwa Tentama

Faculty of Psychology

Universitas Ahmad Dahlan

Kapas Street No. 9, Umbulharjo, Yogyakarta, Indonesia

Email: fatwa.tentama@psy.uad.ac.id

\section{INTRODUCTION}

The government designs vocational high school education as a vehicle for developing knowledge and skills, which is expected to be the answer to the challenges in the workforce sector. Vocational high school graduates are now expected to be able to meet the demands of an increasingly competitive industry. However, the existence of this kind of school is considered to be too premature to prepare graduates to be workers who are ready in terms of knowledge, skills, and psychology. The biggest challenge in the world of education today is to produce graduates who have job readiness or good employability, such as academic ability, ability to master skills, and personality.

Employability skills are a very important basis for every individual in educational institutions, especially in vocational high school. Vocational high schools must prepare their students to have employability as a provision for future employment [1]. Developing and increasing student's employability is clearly an essential thing [2], because it can give students a better skill to manage their careers [3, 4]. Employability can improve teamwork, communication, self-management, analysis, and critical thinking skills [5]. 
The impact of low employability is low self-esteem, lack of effort, and willingness to enter the workforce [6]. Individuals with low employability tend to be more challenging to enter the workforce to get a job they have expected [7]. Besides, a large number of unemployed people today are also caused by the low employability of individuals [8]. Other impacts caused by low employability are inappropriate decision making, conflict, inappropriate leadership, low meta-cognitive skills, ineffective performance, low social responsibility, and pessimism [9].

Employability as a skill is knowledge and competency that can improve an individual's ability to get a job or to enter the job market [10]. Employability refers to the ability of individuals to enter the workforce, adapt to the workplace, and be dynamic in the workplace $[11,12]$. It is the constant ability of individuals to do, to get, or to create work [13, 14]. It is also defined as a form of skill from special skills that enable individuals to identify and realize career opportunities [15].

High or low employability is very much influenced by an individual's belief about their abilities. Therefore, increasing self-efficacy, in general, is the key to increase employability [16]. Characteristics of individuals who have self-efficacy are able to complete difficult tasks, are confident in their abilities, are persistent in achieving goals even though they may not have experienced, and can carry out tasks from start to finish. Previous research also supports that psychological constructs such as self-efficacy can be useful in predicting students' work readiness [17]. Individuals need to understand how important the role of personality (self-efficacy) and individual values are in choosing work items and preparing them [18]. Self-efficacy affects the scope of career choices, job interests, career decision making, and perseverance in difficult fields $[19,20]$. Positive self-efficacy is demonstrated by better career exploration plans [21, 22].

Self-efficacy is a concept that explains human behavior and plays an important role in determining individual choices, levels of effort, and perseverance [23]. Self-efficacy is a personal assessment of one's ability to adopt certain behaviors and actions to achieve specific goals with expected results [24]. It also refers to an individual's evaluation of his skills and competencies in carrying out a task, achieving a goal, or overcoming a problem [25]. Self-efficacy reflects an individual's beliefs about his ability to learn or perform behavior at a specified level, with the hope that the results will refer to his beliefs about the possible consequences of his behavior [26].

One strategy for developing knowledge and expanding cooperation networks is by interacting $[27,28]$. Characteristics of individuals who have good peer interaction are individual openness to the group, acceptance of the presence of individuals in the group, individual involvement in group activities, able to provide ideas for group progress, talk to each other in close relationships and individual intensity in meeting group members. A study found that one of the keys to developing employability while in the school environment is to interact repeatedly with other students [29]. Intensive interactions are the basis for increasing work readiness and orientation in individual career learning [30]. Interaction with peers will develop teamwork skills. Peer peers will also provide information about how to build relationships with fellow students in a career context, what activities to do, and what experiences can be shared [31].

Peer interaction is a process of mutual stimulation and interactivity between at least two individuals of equal position [32]. Peer interaction is a process in which individuals act and react in friendships with one another [33]. It refers to any relationship between two or more individuals [34], who generally spend a lot of time in open spaces with contact intensity [35, 36]. It is defined as the ability of individuals to relate appropriately with other individuals that involve reciprocal behavior [37]. Based on the explanation above, the role of self-efficacy and the peer interaction on employability can be illustrated in Figure 1.

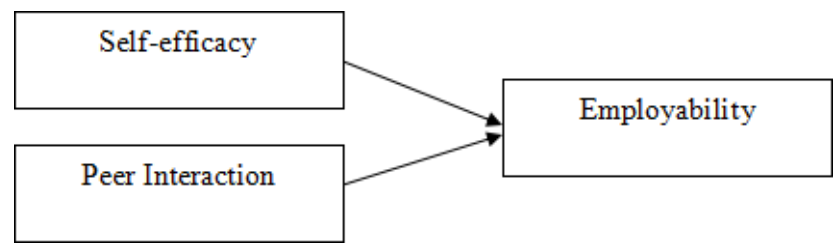

Figure 1. The relationship between self-efficacy and peer interaction towards employability

The formulation of the problem in this study is what is the role of self-efficacy and the peer interaction on student employability? This study aims to empirically examine the role of self-efficacy and the peer interaction on employability in students at Vocational High School Muhammadiyah Prambanan. 


\section{RESEARCH METHOD}

\subsection{Population, sample and sampling techniques}

The population in this study consisted of eight classes totaling 172 students of class XII at Muhammadiyah Prambanan Vocational High School. The sample in this study were 132 students, including six classes and four majors, namely: electrical engineering, light vehicle engineering, motorcycle engineering, and mechanical engineering. The sampling technique was cluster random sampling, this technique is done by selecting a sample that is based on the cluster, not the individual.

\subsection{Measuring instrument}

The data in this study are collected through some scales, including the employability scale, selfefficacy scale, and peer interaction scale. The data collection was carried out by dividing the three research scales directly to the research subjects, namely the employability scale consisting of 24 items, the selfefficacy scale consisting of 15 items, and the scale of peer interaction consisting of 18 items. After the data is collected, then score input data, and analyze it with IBM SPSS Statistics 21.0. The scale in this study has four alternative answers, they are very inappropriate, not appropriate, appropriate, very appropriate, and each scale is divided into a favorable statement and unfavorable statement, with the assessment response using four categories of answers. The scale of employability is expressed in reference to aspects of employability, according to Fugate, et al. [38], namely: career identity, personal adaptability, and social and human capital. The scaling model used for employability is the Likert scale model. Examples of items on the scale of employability are "I have the skills needed in the world of work," "I feel the practical experience at school can help get a job," and "I hope to get a job that suits my major."

The self-efficacy scale refers to aspects of self-efficacy, according to Bandura [39], namely: magnitude, strength, and generality. The scaling model used for the self-efficacy scale is also the Likert scale model. Examples of items on the self-efficacy scale are "I believe I can succeed with the abilities I have, "I master the skills that support me when I work later," and "The abilities I have can make it easier for me to get a job."

The scale of peer interaction is written based on aspects of peer interaction, according to Partowisastro [40], namely: the openness of individuals in groups, the cooperation of individuals in groups, and frequency of individual relationships with groups. Likert scaling model is also used for this scale. Examples of peer interaction scale items are "I have lots of friends," "I like to study together with friends," and "Friends in my group are happy with my presence."

\subsection{Validity and reliability of measuring instruments}

The trial analysis results of 40 subjects on the scale of employability showed that the reliability coefficient $(\alpha)$ is 0.882 with a different power index item (corrected item-total correlation) that moves from 0.310 to 0.672 . Valid and reliable questions that will be used for research are 24 items.

A trial analysis of 40 subjects on a self-efficacy scale showed that a reliability coefficient $(\alpha)$ is 0.880 with a difference in power index item (corrected item-total correlation) that moves from 0.297 to 0.695 . The valid and reliable items that will be used for research are 15 items.

A trial analysis of 40 subjects on a peer interaction scale obtained a reliability coefficient $(\alpha)$ of 0.929 with a different item power index (corrected item-total correlation) that moved from 0.342 to 0.776 . Valid and reliable items that will be used for research are 18 items.

\subsection{Data analysis}

The data are then analyzed with the parametric statistical method. Data analysis is done with IBM SPSS Statistics 21.0, through multiple regression test techniques, which are statistical analysis techniques to determine the role of self-efficacy and peer interaction in predicting employability. Before testing the hypothesis, a descriptive analysis and prerequisite tests consisting of normality, linearity, and multicollinearity tests were conducted.

\section{RESULTS AND DISCUSSION}

\subsection{Descriptive analysis}

Categories for each variable by assigning category criteria are based on the assumption that subjects' scores in the population are normally distributed according to the standard normal curve. The categorization used is the categorization of level based on the normal distribution. The categorization norm is presented in Table 1. Table 1 shows that from 132 subjects research, subjects who had employability in the low category were 15 students $(11.36 \%)$, subjects who had employability in the medium category were 98 students (74.24\%), and subjects who had employability with a high category were 19 students (14.39\%). Thus, the employability categorization of students is moderate. 
Table 1. Employability score categorization

\begin{tabular}{ccccc}
\hline Variable & Interval & Frequency & Percentage (\%) & Categorization \\
\hline \multirow{3}{*}{ Employability } & $X<67$ & 15 & $11.36 \%$ & Low \\
& $67 \leq X \leq 81$ & 98 & $74.24 \%$ & Moderate \\
& $X>81$ & 19 & $14.39 \%$ & High \\
\hline
\end{tabular}

Table 2 shows that from 132 subjects research, subjects who had self-efficacy in the low category were 15 students $(11.36 \%)$, subjects who had self-efficacy in the medium category were 100 students $(75.76 \%)$, and subjects who had self-efficacy with a high category were 17 students $(12.88 \%)$. Thus, the selfefficacy categorization of students is moderate.

Table 2. Self-efficacy score categorization

\begin{tabular}{ccccc}
\hline Variable & Interval & Frequency & Percentage $(\%)$ & Categorization \\
\hline \multirow{3}{*}{ Self-efficacy } & $X<37$ & 15 & $11.36 \%$ & Low \\
& $37 \leq X \leq 51$ & 100 & $75.76 \%$ & Moderate \\
& $X>51$ & 17 & $12.88 \%$ & High \\
\hline
\end{tabular}

Table 3 shows that from 132 subjects research, subjects who had peer interaction in the low category were 18 students (13.64\%), subjects who had peer interaction in the medium category were 97 students $(73.48 \%)$, and subjects who had peer interaction with a high category were 17 students $(12.88 \%)$. Thus, the peer interaction categorization of students is moderate.

Table 3. Peer interaction score categorization

\begin{tabular}{ccccc}
\hline Variable & Interval & Frequency & Percentage $(\%)$ & Categorization \\
\hline \multirow{3}{*}{ Peer interaction } & $X<46$ & 18 & $13.64 \%$ & Low \\
& $46 \leq X \leq 60$ & 97 & $73.48 \%$ & Moderate \\
& $X>60$ & 17 & $12.88 \%$ & High \\
\hline
\end{tabular}

\subsection{Prerequisite test}

\subsubsection{Normality test}

Based on the results of the normality test listed in Table 4, it is known that the significance value of employability, self-efficacy, and peer interaction variables are $0.599,0.110$, and 0.173 , respectively, with $\mathrm{p}>0.05$. It means that each data is usually distributed, and it was concluded that each variable has a normal data distribution.

Table 4. Distribution normality test

\begin{tabular}{cccc}
\hline Variable & Score K-SZ & Significance & Explanation \\
\hline Employability & 0.767 & 0.599 & Normal \\
Self-efficacy & 1.205 & 0.110 & Normal \\
Peer interaction & 1.106 & 0.173 & Normal \\
\hline
\end{tabular}

\subsubsection{Linearity test}

Linearity test results shown in Table 5, obtained F Linearity of 72.013 with a significance level (p) of 0.000 . The test result of peer interaction with employability obtained F Linearity of 47.077 with a significance level of 0.000 , which means linear. Then, it can be said that both self-efficacy and peer interaction have a clear line connection to employability, which relates to linearly.

Table 5. Linearity test

\begin{tabular}{ccccc}
\hline \multicolumn{1}{c}{ Variable } & F Linearity & Significance & Criteria & Explanation \\
\hline Self-efficacy & 72.013 & 0.000 & $\mathrm{P}<0.05$ & Linear \\
Peer interaction & 47.077 & 0.000 & $\mathrm{P}<0.05$ & Linear \\
\hline
\end{tabular}




\subsubsection{Multicollinearity test}

Table 6 shows that VIF value of self-efficacy and peer interaction is $1.363(\mathrm{VIF}<10)$ with the tolerance of 0.734 (tolerance>0.1). Thus, there is no multicollinearity occurring between self-efficacy and peer interaction.

Table 6. Multicollinearity test

\begin{tabular}{lccc}
\hline \multicolumn{1}{c}{ Variable } & Tolerance & VIF & Explanation \\
\hline Self-efficacy & 0.734 & 1.363 & No multicollinearity \\
Peer interaction & 0.734 & 1.363 & No multicollinearity \\
\hline
\end{tabular}

\subsection{Regression analysis test}

Based on the information in Table 7, it can be seen that the role of self-efficacy on employability is obtained a partial value of 0.448 with a significance level of $p$ of $0.000(p<0.01)$, which means self-efficacy plays a very significant role on employability. The purpose of peer interaction on employability obtained a partial value of 0.294 with a significance level of $\mathrm{p} 0.001(\mathrm{p}<0.01)$, which also means the same. It has a very significant role in employability.

Table 7. Partial analysis test result

\begin{tabular}{llccc}
\hline \multicolumn{1}{c}{ Variable } & Partial & Significance & Rule & Explanation \\
\hline Self-efficacy towards employability & 0.448 & 0.000 & $\mathrm{P}<0.01$ & There's a significant role \\
Peer interaction towards employability & 0.294 & 0.001 & $\mathrm{P}<0.01$ & There's a significant role \\
\hline
\end{tabular}

Based on the results of multiple linear regression analysis in Table 8, it is found that self-efficacy and peer interaction can simultaneously contribute to the employability of students in Vocational High School Muhammadiyah Prambanan. These results indicate that the first hypothesis is accepted so that the employability variable can be predicted based on self-efficacy and peer interaction. Simultaneously, the two independent variables contributed $40.8 \%$ to employability, so that the remaining $59.2 \%$ was influenced by other factors. Other factors that affect employability include learning achievement, self-concept [41], career management practices, work experience, training [42], soft-skills, problem solving skills, internship experience factors, and special skill factors [43]. The contribution of self-efficacy to employability is $26.7 \%$, and the contribution of peer interaction to employability is $14.1 \%$ so that self-efficacy contributed more dominantly than peer interaction towards employability.

Table 8. Simultaneous analysis

\begin{tabular}{lccccc}
\hline \multicolumn{1}{c}{ Variable } & $\mathrm{R}$ & $\mathrm{R}$ Square & Significance & Criterion & Explanation \\
\hline $\begin{array}{l}\text { Self-efficacy and peer interaction } \\
\text { towards employability }\end{array}$ & 0.639 & 0.408 & 0.000 & $\mathrm{P}<0.01$ & Very significant role \\
\hline
\end{tabular}

The results of the analysis show that the second hypothesis is accepted, which means that selfefficacy plays a significant role in students' employability. The results of this study support the findings of previous studies, which also found that self-efficacy contributes to the level of student employability [44]. Self-efficacy encourages individuals to engage in various learning and skills development that provide strength for their career readiness. Individuals with low self-efficacy tend to spend more time unemployed than engaging in various job search behaviors so that this is the cause of repeated failures in getting a job [4].

Employability is highly dependent on self-efficacy because an individual's belief in his ability has been shown to be positively related to job search behavior [45]. Self-efficacy requires individuals to strive in various ways or engage in certain behaviors in order to achieve goals (career expectations). This belief illustrates that every individual can take a variety of actions needed to prepare themselves to overcome difficulties associated with the demands of the job market today [46]. The belief that individuals have the attributes, skills, knowledge, experience, and expertise of work to create or attract jobs helps them to explore their career [47]. Thus, self-efficacy is needed by each individual in an effort to get a job [48].

The results of the analysis for the third hypothesis are accepted, which means that peer interaction plays a certain role in students' employability. This finding supports the results of previous studies, which found that peer interactions are responsible for employee employability [49]. Interaction with peers enables 
individuals to jointly identify, analyze, and solve problems, as well as seek and process information to a level that is quite effective and efficient. Also, the information given by peers related to norms and expectations regarding work behavior tends to be more easily accepted [50].

Positive peer interactions can be directed to a decision making an effort related to problem-solving. Each individual has their own ideas and experiences in interaction and by connecting each of these. Knowledge, they can get new knowledge which can later be a solution related to his career [51]. Peer interaction will broaden the analysis of identity and career orientation of individuals. Contributions generated by peer interaction are fostering motivation and career interests, building interpersonal relationships, teamwork, perseverance, increasing understanding of knowledge, compliance with norms, insertion in the work environment, productivity, initiative, ability to take responsibility, creativity in proposing solutions, and confidence in competing in the labor market [52].

The findings of this research are different from previous research. The results of previous research that examined employability found that factors related to employability were self-concept and learning environment [53], entrepreneur intention [54], and responsibility [55], learning achievement [41], motivation to learn and social support [56]. This research is expected to develop the results of previous research to be more comprehensive in uncovering the problems of student employability. The implication of this research is to provide information to students and teachers related to students' employability. The results of this study indicate that self-efficacy and peer interaction can contribute to the student to be better prepared to enter the workforce. Peers play a significant role as the ones who provide and share information and allow interaction to happen. Therefore, by conducting intensive interactions, the individual can get new insights related to his career later. Besides, the results of interaction with peers can also foster individual confidence in his ability to get a job. The results of the study can be used as a reference to motivate students to have positive beliefs about their abilities because self-efficacy has a more dominant contribution in increasing the employability of students in the Vocational High School Muhammadiyah Prambanan. Thus, it is hoped that students will have better readiness to enter the job market.

\section{CONCLUSION}

Employability is a very important thing to have in class XII students who will graduate to find work and carry out work. Students' work readiness needs to be prepared early in the education process at the Vocational High School. Students in class XII at Muhammadiyah Prambanan Vocational High School mostly have a moderate level of employability so it needs to be increased again by paying attention to the factors that influence it, including self-efficacy and peer interaction. Self-efficacy and peer interaction can simultaneously contribute to the employability students of class XII at Muhammadiyah Prambanan Vocational High School. The contribution of self-efficacy and the peer interaction on employability was $40.8 \%$. The contribution of self-efficacy to employability is more dominant than that of peer interaction to employability.

\section{ACKNOWLEDGEMENTS}

The authors would like to thank the Faculty of Psychology of Universitas Ahmad Dahlan and Vocational High School Muhammadiyah Prambanan for the technical assistance in this study. The authors also thank all participating students, teachers, school administrators, and other individuals for their efforts, assistance, and involvement in this research.

\section{REFERENCES}

[1] Y. F. Wang and C. T. Tsai, "Employability of hospitality graduates: Student and industry perspectives," Journal of Hospitality \& Tourism Education, vol. 26, no. 3, pp. 125-135, 2014.

[2] S. M. Jameson, "A case study of international hospitality students' development of employability skills," Tourism and Hospitality Research, pp. 57-59, 2008.

[3] N. Hess, D. M. Jepsen, and N. Dries, "Career and employer change in the age of the 'boundaryless' career," Journal of Vocational Behavior, vol. 81, no. 2, pp. 280-288, 2012.

[4] S. McArdle, L. Waters, J. P. Briscoe, and D. T. T. Hall, "Employability during unemployment: Adaptability, career identity and human and social capital," Journal of Vocational Behavior, vol. 71, no. 2, pp. 247-264, 2007.

[5] K. Lowden, S. Hall, D. Elliot, and J. Lewin, Employers' perceptions of the employability skills of new graduates. London: Edge Foundation, 2011.

[6] R. Benabou and J. Tirole, "Self-confidence and personal motivation," The Quarterly Journal of Economics, vol. 117, no. 3, pp. 871-915, 2002.

[7] M. Yorke and P. Knight, "Evidence-informed pedagogy and the enhancement of student employability," Teaching in Higher Education, vol. 12, no. 2, pp. 157-170, 2007. 
[8] P. Ronnås and L. Shamchiyeva, Employment diagnostic analysis: Maluku, Indonesia. Geneva: International Labour Organization, 2011.

[9] D. Jackson and E. Chapman, "Non-technical skill gaps in Australian business graduates," Education + Training, vol. 54, no. 2/3, pp. 95-113, 2012.

[10] L. Brewer, Enhancing youth employability: What? Why? And How? Guide to core work skills. Geneva: International Labour Organization, 2013.

[11] M. Coetzee and H. Roythorne-Jacobs, Career counselling and guidance in the workplace: A manual for career practitioners. Cape Town: Juta and Company Ltd., 2007.

[12] E. Herr, S. Cramer, and S. Niles, Career guidance and counselling through the lifespan. London: Prentice Hall, 2004.

[13] D. T. Hall and D. E. Chandler, "Psychological success: When the career is a calling," Journal of Organizational Behavior: The International Journal of Industrial, Occupational and Organizational Psychology and Behavior, vol. 26, no. 2, pp. 155-176, 2005.

[14] C. M. Van der Heijde and B. I. Van Der Heijden, "A competence-based and multidimensional operationalization and measurement of employability," Human Resource Management, vol. 45, no. 3, pp. 449-476, 2006.

[15] M. Fugate and B. E. Ashforth, "Employability: The construct, its dimensions, and applications," Academy of Management Proceedings, vol. 1, pp. 1-6, 2003.

[16] R. Hazenberg, F. Seddon, and S. Denny, "Programme recruitment and evaluation: The effect of an employability enhancement programme on the general self-efficacy levels of unemployed graduates," Journal of Education and Work, vol. 28, no. 3, pp. 273-300, 2015.

[17] M. Yorke and L. Harvey, "Graduate attributes and their development," New Directions for Institutional Research, vol. 4 , no. 128 , pp. 41-58, 2005.

[18] G. Gbadamosi, et al., "Employability and students' part-time work in the UK: does self-efficacy and career aspiration matter?" British Educational Research Journal, vol. 41, no. 6, pp. 1086-1107, 2015.

[19] G. D. Markman, D. B. Balkin, and R. A. Baron, "Inventors and new venture formation: The effects of general selfefficacy and regretful thinking," Entrepreneurship Theory and Practice, vol. 27, no. 2, pp. 149-165, 2002.

[20] D. Olwage, "Predictors of burnout and engagement of university students," Ph.D. Dissertation, North-West University, Potchefstroom, South Africa, 2012.

[21] K. Austin and F. Cilliers, "The psychometric relationship between career thinking and salutogenic functioning amongst unemployed adults," Journal of Industrial Psychology, vol. 7, no. 1, pp. 1-11, 2011.

[22] L. A. Ochs and R. T. Roessler, "Predictors of career exploration intentions: A social cognitive career theory perspective," Rehabilitation Counseling Bulletin, vol. 47, no. 4, pp. 224-233, 2004.

[23] G. Chen, M. S. Gully, and D. Eden, "General self-efficacy and self-esteem: Toward theoretical and empirical distinction between correlated self-evaluations," Journal of Organizational Behavior, vol. 25, no. 3, pp. 375-395, 2004

[24] W. K. Hoy and C. G. Miskel, Educational administration: Theory, research and practice. New York: Mc GrawHill, 2012.

[25] R. A. Baron and D. Byrne, Social psychology: Understanding human interaction. Boston: Allyn and Bacon, 2002.

[26] D. L. Feltz, and T. M. Magyar, "Self-efficacy and adolescents in sport and physical activity," Adolescence and Education, vol. 4, pp. 161-179, 2006.

[27] M. I. Dascalu, B. Tesila, G. Dragoi, and C. N. Bodea, "Intelligent virtual communities to sustain lifelong learners and related recruitment processes," eLearning \& Software for Education, vol. 1, pp. 524-531, 2015.

[28] P. A. Tess, "The role of social media in higher education classes (real and virtual): A literature review," Computers in Human Behavior, vol. 29, no. 5, pp. 60-68, 2013.

[29] C. Jones, "Creating employability skills in SMEs: Modification through interaction," Industry and Higher Education, vol. 19, no. 1, pp. 25-34, 2005.

[30] European Commission, Promoting employability through higher education. Directorate-General for Education and Culture: Brussels, 2015.

[31] C. N. Bodea, M. I. Dascalu, M. Huemann, G. Velikic, and R. I. Mogos, "Social media information systems and graduate employability: A qualitative regional research," Issues in Information Systems, vol. 19, no. 3, pp. 53-60, 2018.

[32] R. Hari and M. V. Kujala, "Brain basis of human social interaction: From concepts to brain imaging," Physiological Reviews, vol. 89, no. 2, pp. 453-479, 2009.

[33] V. Mele, Social interaction. New Jersey: John Wiley \& Sons, 2017.

[34] M. L. Kringelbach and E. T. Rolls, "Neural correlates of rapid reversal learning in a simple model of human social interaction," Neuroimage, vol. 20, no. 2, pp. 1371-1383, 2003.

[35] M. Carmona, S. Tiesdell, T. Heath, and T. Oc, Public places-urban spaces: The dimensions of urban design. New York: Architectural Press, 2010

[36] J. Gehl, Cities for people. Washington: Island Press, 2011.

[37] S. G. Little, J. Swangler, and A. Akin-Little, Defining social skills. Berlin: Springer, 2017.

[38] M. Fugate, A. J. Kinicki, and B. E. Ashforth, "Employability: A psycho-social construct, its dimensions, and applications," Journal of Vocational Behavior, vol. 65, no. 1, pp. 14-38, 2004.

[39] A. Bandura, Self-efficacy. San Francisco: Stanford University, 2010.

[40] K. Partowisastro, The dynamics of social psychology (in Bahasa). Jakarta: Erlangga, 2009. 
[41] F. Tentama and M. H. Abdillah, "Student employability examined from academic achievement and self-concept," International Journal of Evaluation and Research in Education (IJERE), vol. 8, no. 2, pp. 243-248, 2019.

[42] N. Juhdi, F. Pa'Wan, N. A. Othman, and H. Moksin, "Factors influencing internal and external employability of employees," Business and Economics Journal, vol. 11, pp. 1-10, 2010.

[43] D. J. Finch, L. K. Hamilton, R. Baldwin, and M. Zehner, "An exploratory study of factors affecting undergraduate employability," Education + Training, vol. 55, no. 7, pp. 681-704, 2013.

[44] N. Whelan, S. McGilloway, M. P. Murphy, and C. McGuinness, "EEPIC-Enhancing employability through positive interventions for improving career potential: The impact of a high support career guidance intervention on the wellbeing, hopefulness, self-efficacy and employability of the long-term unemployed-a study protocol for a randomised controlled trial," Trials, vol. 19, no. 141, pp. 1-18, 2018.

[45] R. Kanfer, C. R. Wanberg, and T. M. Kantrowitz, "Job search and employment: A personality-motivational analysis and meta-analytic review," Journal of Applied Psychology, vol. 86, no. 5, pp. 837-855, 2001.

[46] R. Kreitner, and A. Kinicki, Organizational behavior. New York: McGraw-Hill, 2012.

[47] M. Coetzee, and A. Schreuder, "The relation between career anchors, emotional intelligence and employability satisfaction among workers in the service industry," Southern African Business Review, vol. 15, no. 3, pp. 76-97, 2011.

[48] M. Van der Velde, and P. Van den Berg, "Managing functional flexibility in a passenger transport firm," Human Resource Management Journal, vol. 13, no. 4, pp. 45-55, 2003.

[49] R. Junco, J. M. Mastrodicasa, A. V. Aguiar, E. M. Longnecker, and J. N. Rokkum, "Impact of technology-mediated communication on student evaluations of advising," NACADA Journal, vol. 36, no. 2, pp. 54-66, 2016.

[50] A. E. Green, M. De Hoyos, S. A. Barnes, D. Owen, B. Baldauf, and H. Behle, Literature review on employability, inclusion, and ICT, report 1: The concept of employability with a specific focus on young people, older workers and migrants. Luxembourg: Publications Office of the European Union, 2013.

[51] M. Yorke and P. T. Knight, Embedding employability into the curriculum: The higher education academy. New York: The Higher Education Academy, 2006.

[52] C. Costa-Lobo, F. C. Lopes, C. Santos-Pereira, N. Durão, and M. Magalhães, "Human interaction skills and employability at information technology internships," International Conference on Lifelong Education and Leadership for All Iclel, Polytechnic Institute of Porto, Porto, 2017.

[53] F. Tentama and H. D. Jayanti, "Self-concept, perception of the learning environment and employability: A study of vocational high school students in Prambanan Yogyakarta, Indonesia," Humanities \& Social Sciences Reviews, vol. 7, no. 1, pp. 433-440, 2019.

[54] F. Tentama and S. Yusantri, "The role of entrepreneurial intention in predicting vocational high school students employability," International Journal of Evaluation and Research in Education (IJERE), vol. 9, no. 3, pp. 558-563, 2020.

[55] F. Tentama and N. Merdiaty, "Analysis of factors that affect employability and its implications," Humanities \& Social Sciences Reviews, vol. 8, no. 3, pp. 238-245, 2020.

[56] F. Tentama, Subardjo, and M. H. Abdillah, "Motivation to learn and social support determine employability among vocational high school students," International Journal of Evaluation and Research in Education (IJERE), vol. 8, no. 2, pp. 237-242, 2019. 